\title{
Communications Policies and the Production of Audiovisual Content in Argentina
}

\author{
Carla Rodríguez Miranda \\ Ornela Carboni
}

\begin{abstract}
The introduction of digital terrestrial television and the passage of the Audiovisual Communications Services Act in Argentina in 2009 led to a series of competitions to stimulate the production of new content and help dismantle the prevailing center-periphery logic in Argentine television. An examination from the perspective of the political econ- omy of communications of these efforts in 2011-2013 indicates that they were small steps in the right direction. Further progress will require a stable source of funding, a stronger role for public televisión, and new strategies for capturing viewers.
\end{abstract}

La implementación de la televisión digital terrestre y la sanción de la Ley de Servicios de Comunicación Audiovisual en Argentina en 2009 dio lugar a una serie de concursos para estimular la producción de nuevos contenidos y ayudar a desmantelar la lógica cen- tro-periferia que predomina en la televisión argentina. Un análisis desde la perspectiva de la economía política de la comunicación de estos esfuerzos durante el periodo 2011-2013 da muestra de pequeños pasos en la dirección correcta. Para un mayor progreso se requerirá de una fuente de fondos estable, un papel fortalecido para la televisión pública, y nuevas estrategias para captar televidentes.

Keywords: Communications policies, Digital television, Production of content, Government, Argentina

Since 2009, Argentina has experienced a new phase in regulatory policies for audiovisual communications media inaugurated by the passage of the Audiovisual Communications Services Act. The new standards are character- ized by efforts to reduce concentration, promote the development of nonprofit sectors, encourage nationwide production of content for radio and television, and reconfigure the enforcement authority. Since the return of democracy in 1983, this authority had been under the executive branch. The new law created the Autoridad Federal de Servicios de Comunicación Audiovisual (Federal Audiovisual Communications Service Authority-AFSCA), which is decen- tralized and autonomous, with a board of directors chosen by the executive branch and the legislative blocs. At the same time, the Japanese-Brazilian Integrated Services Digital Broadcasting system, 
advanced by the state under the umbrella of its Planning Ministry, was chosen for the development of digi- tal terrestrial television. The series of objectives identified in this regard included the development of the network infrastructure, the promotion of access to digital technology, and the production of content.

In this context, this article examines how the production of high-definition audiovisual content was planned and encouraged with the goal of federalizing television, which has historically been characterized by centralization in the city of Buenos Aires. Adopting the perspective of the political economy of com- munication (Mosco, 2006), we examined the communication policies for the production of audiovisual content to discover the degree to which the prevail- ing centralist rationale was altered. We reconstructed the regulations and com- petitions aimed at financing high-definition fiction products for television, studied the coordination between the stages of the value stream, and, lastly, evaluated progress toward the goal of inclusion and federalism.

The article is organized into four sections. First, we explain our theoretical perspective and look closely at the description of the television industry. Then we analyze the issue's historical context. Next we look at the production of high-quality fiction content, and finally we summarize the principal findings of the investigation.

\section{Television as a cultural industry}

The theoretical perspective of the investigation focused on the political econ- omy of communications, studying industrialized activities of the culture and social relations (with an emphasis on power relations) that constitute the pro- duction, distribution, and consumption of communications resources (Mosco, 2006). Becerra (2014) contends that these activities are both historically consti- tuted and constituent in that they are at once structured by the political, cul- tural, and economic history of the country and structuring elements of society. Along that line, this study examines the relationships established between the government and the communications companies, the processes of concentra- tion/deconcentration of media markets, regulatory policies, and the promotion of content production, keeping in mind the relationship between the physical and the symbolic production of cultural assets.

The cultural industries produce and distribute merchandise with sym- bolic 
content aimed at consumer markets as a function of ideological and social reproduction (Zallo, 1988). The goods involved have a dual value: economic (the reproduction of capital) and symbolic (the transmission of values and social identifications) (Pasquali, 1991). The Internet hosts these industries in their forms of valorization. The restructuring of the television industry and predictions about its future or its alignment with current ways of making and watching television call for an examination of its rationales of production and operation and the government's interest in stimulating the production of content.

\section{Open digital television in context}

Digital migration of open television is a nationwide process (Bustamante, 2003) tied to the regulation, structure, and economic model inherited from analog television (Galperin, 2004). Digitalization of an open television signal transmitted through the air can allow improved image and sound quality, mul- tiple programming, and interactive and mobile services. These strengths foster renewal of the audiovisual scene through the entry of new players and a range of services and applications. Digital television, as a mass-point network, is a technology that needs to be adjusted to the changes in supply and consumption patterns of audiovisual content brought about by the Internet. In the European and U.S. experiences, its deployment did not deliver on the technology's prom- ise, and, although in some cases new players emerged in the production of content and distribution (Albornoz and García Leiva, 2012), it retained the structure inherited from analog television. In addition, Latin American coun- tries were in transition, with Mexico set to make the analog switch-off in 2015 and the remainder expected to do so between 2016 and 2020. Brazil was notable for its proposal to guarantee a mirror digital channel for private signals, desig- nating four channels for use by TV NBR (belonging to the executive branch) and creating separate channels for education, culture, and citizenship. In 2007 the Empresa Brasileña de Comunicación (Brazilian Communications Company) was formed to manage the public communications system, responsible for TV Brasil and TV Brasil Internacional (created in 2007 and 2010 respectively). The company was charged with launching an audiovisual platform that would house 20 signals through its own transport network to include, in addition to those already mentioned, the signals of the three national government 
branches. In Colombia, digital television inspired the pursuit of content that broke with the traditional model of general programming. The Ministry of Technology signed coproduction agreements with international producers to strengthen public television, and regional channels signed accords with universities for the production of content. Nevertheless, the public channels Colombia, 1, and Institucional and the regional channels are not governed by a unified public television policy with regard to the digital transition.

Similarly, in Argentina digitalization for open television has been the subject of debate regarding the role of the media under democracy, especially since the passage of the Audiovisual Communications Services Act. Tensions between political power and media power became public in March 2008 during a con- flict between the government and the traditional rural organizations. One of the core issues was media coverage of a resolution of the Ministry of the Economy that changed the application of export rights in the agricultural sec- tor. Despite not having been approved by Congress, this resolution dismantled certain power logics and triggered a confrontation between the government and the Grupo Clarín. With President Cristina Fernández's speech during the opening of Congress in 2009, the passage of a law concerning the regulation of audiovisual media became part of the government's agenda. Since the return to democracy there had been a demand for change in the radio broadcast law issued under the military government of 19761983 and modified several times thereafter, but some members of the business media opposition ${ }^{1}$ had argued that the bill restricted freedom of expression.

After the passage of the Audiovisual Communications Services Act, the debate centered on the composition of the supervisory and management bod-ies in the text of the law and on the adjudication of its regulations. ${ }^{2}$ Full enforce- ment was slowed by the major multimedia groups and even by the state itself. The law maintains that audiovisual activity is in the public interest and includes among its goals the promotion of diversity and universality in access and equal participation for every resident. It establishes changes in the enforcement authority, reserves 33 percent of the radio spectrum for the nonprofit sector, reduces the limits on licenses (forcing multimedia groups to divest), and fixes national production quotas. Most important, it positions the state as the guar- antor of the right to communication (Marino, Mastrini, and Becerra, 2010).

Passage of the law further strained the relationship between the govern- ment 
and Grupo Clarín, Argentina's main media group, whose influence extends to various media throughout the country (radio, open and cable tele- vision, newspapers, news agencies). From the moment it was adopted there was litigation against it. The Argentine researcher Santiago Marino (2013) explains that enforcement of the regulations was distorted by external motives such as the Grupo Clarín's repeated calls for a halt to the enforcement of the rules on key points linked mainly to divestment and deconcentration of media oligopolies and the enforcement authority's concerns about, among other things, the lack of a technical frequencies plan and the reservation of part of the spectrum for nonprofit operators in areas of conflict. One pivotal event was the call by the Supreme Court for public hearings including an amicus curiae in the dispute between Grupo Clarín and the government. These hear- ings helped to defuse the conflict, and in 2009 the court declared Articles 41, 45, 48, and 161 of the law constitutional.

Concurrently, the government adopted the Japanese-Brazilian Integrated Services Digital Broadcasting standard for digital television. The standard had the advantage over competing ones of allowing the transfer of audiovisual content through mobile telephones without using the telecommunications networks. In addition, it promoted the development of Ginga middleware, an open system for interactive services. In geopolitical terms, the choice of it was seen as the starting point for enhancing the region's economic, technological, and cultural resources. In addition, the Sistema Argentino de Televisión Digital Terrestre was created under the Planning Ministry with an advisory council for its implementation. Network infrastructure was developed, and decodifi- ers for adapting old television sets to digital technology were distributed free of charge to the most vulnerable sectors of the population through the MiTV digital program.

Here it is appropriate to point out that, while the logic of physical access to the old mass-point technologies meant obtaining a television that was a dura- ble asset, with access to digital technologies this definition of physical access is inadequate (Van Dijk and Hacker, 2003). Access to the Internet implies a first level of physical access that varies with the user's capacity to pay for faster broadband service and to upgrade technologically, since the equipment and operative systems become obsolete at a dizzying rate. However, a political decision was made in 2006 to stimulate technological changes in the commu- nication sector to guarantee physical access, producing Plan Argentina Conectada ${ }^{3}$ and Plan Conectar Igualdad, ${ }^{4}$ 
among others. These programs overlap with an industrial policy for boosting domestic production and the creation of direct and indirect employment. In 2008 the 2005 binational agree- ment with Brazil was reinstated (Rodríguez Miranda, 2010), and in 2009 these industrial designs were linked to specific communications policies that in part arose from the new law. In this setting, the state played an unprecedented role in the implementation of digital television with the intention ot guaranteeing social and digital inclusion.

Digital television entered a media system with a conglomerate structure led by Grupo Clarín, with minimal participation of foreign capital, and Grupo Telefónica, with transnational capital (Becerra and Mastrini, 2009). The televi- sion market is medium-sized, concentrated under the duopoly of Channel 13 (Grupo Clarín), dominant in subscription television, and Channel 11 (Grupo Telefónica), dominant in the telecommunications sector. Pay-TV reaches 74 per- cent of homes, or 8.5 million, of which 82 percent is through the cable system and 18 percent by satellite. ${ }^{5}$ In addition there are over-the-top services (such as Netflix) that run on the Internet and can be consumed on multiple screens. An audiovisual platform has been under development since 2010 through four ultrahigh-frequency channels (22-25) granted to the state-owned company Radio y Televisión Argentina (RTA) and declared in the public interest. It also houses a set of signals (public and private) that have a tenuous operating per- mit. These authorizations are granted on a discretionary basis and are justified in terms of the absence of the technical plan to be developed by the AFSCA.

According to the official digital television site, the platform has 37 signals, of which 14 are public, 14 private, 6 belong to the third sector, and 2 have not provided information. Fifteen of these have a national reach: TV Pública- Channel 7, Encuentro, Paka, Ta Te Ti, Incaa TV, TecTV, DeporTV, Telesur, Construir TV, Vivra, Arpeggio, Viajar TV, 360, $\mathrm{C} 5 \mathrm{~N}$, and CN23. Of this subset 8 are public, 6 private, and 1 from the third sector. Ten of them were created for the digital television platform; some later switched to broadcasting simultane- ously in the pay-TV systems. Of the remaining 22 signals, 9 broadcast from the city of Buenos Aires and the metropolitan area, 2 from the city of La Plata, 2 from the city of Córdoba, 2 from the city of Mendoza, and 1 each from the cities of: Formosa, San Salvador de Jujuy, Santa Rosa, Posadas, Rosario, Santiago del Estero, and La Rioja. Of the principal private open signals, Telefe, Channel 9, and América are available only on the platform for the city 
of Buenos Aires and the metropolitan area. In the rest of the country they are transmitted over repeaters or by subscription television. Channel 13 is not part of the platform because of the dispute between the government and Grupo Clarín, but it broad- casts on an aerial ultrahigh-frequency channel granted through a resolution to carry out experimental testing as its peers within the coverage area do. In addition, in 2013 the AFSCA authorized 33 low-power transmitters to broadcast in analog with a temporary permit without the capacity of sending their signals to the digital platform, since it was managed by the RTA. Of the 33 percent of the radio spectrum reserved for the nonprofit sector (Articles 21 and 89 section f), only the national Construir TV, belonging to the construction union, and the university signals with local reach were allowed to broadcast in digital. The latter were located on a part of the spectrum (ultrahigh-frequency Channels 55 to 66) that might be affected by the call for bids on frequencies for mobile tele- phony under the Communications Department's Resolution 1814 of 2014.

New Internet audiovisual proposals have arisen in the new digital setting, but viewers have not stopped watching television. Rather, their attention is divided among mobile telephones, notebooks, and tablets, and this makes it necessary to identify their consumption patterns in order to generate applica- tions and software for the numerous platforms. Linking the developers with the producers of television content is crucial for advancing digital television, innovating on a strategy of product differentiation that takes advantage of the convergence. Generating attractive content is a fundamental element of promo- tion. Article 65 of the Audiovisual Communications Services Act stipulates that radio broadcasting services must transmit a minimum of 60 percent in domes- tic production and a minimum of 30 percent of their own production. Accordingly, programs have been established by the Instituto Nacional de Cine y Artes Audiovisuales (National Institute of Film and Audiovisual Arts- INCAA) in conjunction with the Planning Ministry, the Universidad Nacional de San Martín (National University of San Martin-UNSAM), and the Consejo Interuniversitario Nacional (National Interuniversity Council-CIN). On one hand, there were national-level competitions to promote and produce content, which later became part of the Banco de Contenidos Universales Argentino (Argentine Universal Content Bank-BACUA), a digitalized network for pre- serving the nation's audiovisual memory and supplying audiovisual content of universal scope that could be used by public, private, or third-sector chan- nels and 
viewed through via streaming. In addition, technological audiovisual program poles were designed in conjunction with public universities to pro- mote local productive systems composed of various public and private sectors.

The implementation of audiovisual communication policies was marked by a certain amount of lack of coordination, discretionary action, and breakdown between the letter of the law and the goals of digital television. In four years digital television had reached 85 percent of the population, multiprogramming was promoted with 15 national signals, and the production of content was enhanced in an effort to generate attractive offerings. However, according to the Ministry of Culture digital television coverage reaches only 7 percent of the population.

\section{Stimualting production of digital content}

With the passage of the Audiovisual Communications Services Act and the implementation of digital television, one focus of communications policies became the stimulation of the production of audiovisual content. This effort was aimed at creating a reservoir of content for the new digital signals that would be formalized as digital television was implemented. In addition to creating the BACUA, another aim was reversing the centralization of content production in Buenos Aires. According to the AFSCA's annual report on open television content, during 2011 prime Channels 11 and 13 maintained approximately 70 percent of the country's retransmitted content. These initiatives sought to break with the traditional centralization and create productive capacity around the country. To this end, the Operative Plan for Stimulus and Promotion of Digital Audiovisual Content was approved for television in 2010, and thereafter the Planning Ministry, the UNSAM, the CIN, and the INCAA conducted annual national competitions to stimulate production. These

competitions were divided up according to format (documentary, fiction, entertainment), the pro- duction experience of the applicants, budget, and future means of distribution. There were national contests (documentary series for public channels, docu- mentaries and fiction for experienced producers, national cartoon series, fiction series for public channels), regional contests (fiction, thematic fiction, and national documentary series, the national Nosotros show, thematic cartoon series, model programs for public channels), and contests for the high-definition fiction series that are the focus of this analysis. Assessment of the competitions was done by 
a panel of judges made up of recognized professionals in national television and/or cultural fields: screenplay writers, producers, directors, film and television actors, members of the INCAA, the AFSCA, the unions of the Confederación Sindical de los Trabajadores de los Medios de Comunicación Social, and the organizations that represent the new voices emerging from the passage of the Audiovisual Communications Services Act.

According to the AFSCA (2012), 59,000 hours of audiovisual content promoted by the state had been produced since 2010, which translates into 940 fiction and documentary productions used by 50 channels. At the same time, 100,000 jobs had been created in the audiovisual industry. Nevertheless, it was impossible to establish a sustainable financial model for this type of project.

\section{The production of high-definition series}

Competition for the high-definition fiction series was aimed at the open television channels, either alone or in conjunction with other experienced producers (producers with at least one audiovisual production more than 30 minutes long shown in movie theaters or on open television or cable channels. Three editions were filmed between 2011 and 2013). These productions had very large budgets and, except for four, were the work of producers (television or film) that partnered with one of the Buenos Aires channels. This dynamic highlights the dichotomy between inclusive national television and centralized Buenos Aires television.

The projects selected had to be shown on open television channels in prime time (Monday through Friday from 8 p.m. to midnight). The content was to become part of the BACUA, and the producers/directors had to cede their intellectual property rights to the government. However, the open television channels or winning producers retained the international marketing rights to their work, except in Latin America, for 24 months. Finally, if the show had been developed by a producer associated with an open television channel, it had to be accompanied by a legal instrument that explained the relationship between the parties. Between 2011 and 2013, 38 high-definition fiction series, ranging from 8 to 13 chapters each, were developed. Some were shown on open television channels, but only 4 were broadcast on channels not in the city of Buenos Aires or the metropolitan area. Two 
went online on the open digital content page, and some of the 2013 winners were recorded.

In 2011, 10 series were financed. Each of the fiction winners received a total budget of 4,550,000 pesos (approx. US\$1 million), equal to 50,000 pesos (approx. US\$7,435) for each of the 13 48-minute episodes. Grupo Clarín's Channel 13, despite being part of PolKa, one of the country's main producers of fiction, does not participate in this type of competition because of the group's relationship to the government. Despite having a high level of original fictional production, Telefe does participate. For their part, América TV and Channel 9 do not usu- ally generate fictional content and therefore have profited from these contests. In 2012 and 2013 the second and third editions of fictional series projects were conducted, with the same goals as the first and larger budgets assigned to each. Most of the productions were conducted by producers with experience in the audiovisual field. Some of them were strictly linked to the television sector (Underground, GP Medios, LC Acción, Promofilm Imagina, Eyeworks 4 Cabezas, Torneos y Competencia), others to the film sector (Tres Mentes SA, Sudestada Cine SRL, Campo Cine, Lagarto Cine, Oruga Films, Haddock Films SRL, Azteka Films SRL), some were created for the occasion (Atuel Producciones, Zoelle Producciones, Tostaki SA), and others were linked to renowned actors in the audiovisual field or linked to the universities (Gastón Gularte, Albertina Carri, Universidad Nacional del Litoral, Universidad Nacional del Centro de

la Provincia de Buenos Aires).

Although the objective of stimulating production was based on advancing the production of quality national content in order to break away from central- ism, a systematic approach allows us to see that a large proportion of the pro- ducers are located in the city of Buenos Aires, showing the complexities that arise in the attempt to reverse centralism and the concentration of production in the metropolitan area. Once the initial data were collected on the installed capacity in each of the regions, the challenge was to design proposals that would ensure stable financing procedures that were not tied to the discretion and budgets of the administration in power. 


\section{The lag in federalization of television}

The digital television platform is composed of 37 channels, of which 14 have nationwide coverage and reach 85 percent of the country and 7 percent of the population. Of the 22 productions carried out in 2011-2012, 6 were transmitted by Channel 9, 4 by América TV, and 2 by Telefe, all open private channels avail- able on the digital television platform only in the city of Buenos Aires and the metropolitan area. Of the remainder, 1 production was transmitted by Channel 10 (Mar del Plata) in 2011 and 4 productions by Channel 7, 1 by Channel 12 (Posadas), 1 by Channel 9 (Litoral), and 1 by Channel 12 (Trenque Lauquen) in 2012. Two others from 2012 were not shown on a television channel but were available on open digital content, a video-on-demand service available on the Web and on Phillips Smart TV and, through their NetCast platform, LG televi- sions and tablets and mobile telephones with iOS (iPhone, iPad, iPod) or Android. This over-the-top system makes it possible for not all content to belong exclusively to the network operator.

The miniseries that won the 2011 competition, Maltratados, shown on América 2 , achieved an average rating of 4.3 points. When El Donante, broad- cast on Telefe in 2012, did not get the expected rating, it was dropped from prime time. Las huellas del secretario, shown on Channel 7, had the fewest viewers, earning an average of 1.1 points in 2011. In 2012 Historia clínica, shown on Telefe on Saturdays, had the most viewers, with an average of 5.7 points. Ratings on open television were led by Telefe and Channel 13. Private channels managed to capture more viewers than the state channel, a dialectic inherited from the analog world. Channel 7's screen has not taken off despite its commitment to programming aimed at different publics and viewers (sports, fiction, documen- tary, educational, and children's shows). Nevertheless, while 9 productions were transmitted by private channels without national coverage through digi- tal television in 2011, this number dropped to 4 productions in 2012. Productions by Channel 7 and on open digital content increased in number, with 4 and 2 respectively. Of the 16 productions from 2013, 3 were transmitted by Channel 9 and one by Telefe. Five productions were available on open digital content. From this it can be inferred that there was less interest on the part of the tradi- tional private and public channels in transmitting high-definition productions than in 2011 and 2012.

Most high-definition productions were transmitted by private channels that the digital television platform provided only in the city of Buenos Aires and the 
metropolitan area., where pay-TV has penetrations of 86.7 percent and 80 per-cent, respectively, and the television viewer watches these shows for pay. In provinces such as Santiago del Estero and Misiones, these shows were unavail- able in almost half of the households, since only 43.8 percent and 50.5 percent, respectively, pay to watch television. ${ }^{6}$ Thus, despite policies and the infusion of public financing, the goal of a nationwide television service in both production and transmission is being approached at a crawl. Nevertheless, there was a shift in transmission in 2013. An increase in content broadcast through open digital content bypassed the requirement for the competition of partnering with a channel for the transmission of a series, and it also marked a shift toward convergent consumption in that users could now choose the screen for watch-ing content provided that they had access to a broadband connection. Therefore, aiming to guarantee a broadband connection as a universal service at optimal speeds could accelerate the progress of a federal audiovisual policy for the transmission phase.

These initiatives are promising and will be successful to the extent that they meet the objectives of inclusion and federalization. Thus the challenge for digital television is to separate itself from the rationales that tie it to centralized dependency. The pursuit of a techno-productive policy will be successful to the degree that digital television achieves autonomy in its regulations and actions through an audiovisual space that articulates the goals of cultural diversity and informational pluralism at the service of the whole population.

\section{Reflections}

This essay has systematized a set of data linked to the stimulation of audio- visual content production in the context of implementing digital television and the Audiovisual Communications Services Act. The competitions conducted for fiction series in full high-definition have been surveyed and the producers that benefited and their broadcasting channels identified. It has become clear that, while the exercise fostered the entry into digital television of new players from the cinematic and university sectors, in the short term it was uncertain whether this effect was sustainable. From 2011 to 2013 a total of 20 productions was released; 14 were broadcast by the private channels in Buenos Aires (América TV, Channel 9, and Telefe), 3 by Channel 7, and the rest by Channel 10 (Mar del Plata), Channel 12 
(Posadas), Channel 9 (del Litoral), and Channel 12 (Trenque Lauquen). In addition they were available on open digital content. Eight fiction shows were awaiting release in 2014.

The fact that a product originally designed for television can be used on several platforms allows economies of scale in the distribution phase, but the multiplicity of screens does not necessarily serve the goal of digital inclusion. This is because access to the Internet depends on the user's ability to pay for it and because most series are transmitted by free, open private channels through digital television only in the metropolitan area and the city of Buenos Aires. In this connection, a first response to the question whether centralization in the production and transmission of audiovisual content was achieved in the period in question is that the city of Buenos Aires remained predominant. Nevertheless, these policies did serve as a stimulus to the generation of productive capacities in new geographic areas. At the same time, most of the new players that emerged came from the film industry, perhaps because of the participation of the INCAA in the project. As a result, there was convergence of cinematic and television culture with respect to aesthetics and forms of production.

Considering all of the above, one of the challenges is coordinating policies and linking these initiatives with medium- and long-term policies that are not tied to the discretion of the government in power. To this end, a stable flow of production financing and stimulation of self-financing through alliances with the public sector and cooperation agreements with the private sector, thereby strengthening the role of public television, will be necessary. It will also be nec- essary to create public communications strategies and attractive formats for capturing viewers for whom physical access is guaranteed. 


\section{Notes}

1. Including the Asociación de Entidades Periodísticas de Argentina, the Asociación de Diarios del Interior de la República Argentina, the Asociación de Radiodifusores Privados de la Argentina, the Asociación de Teleradiodifusoras Argentinas, the Asociación Argentina de Televisión por Cable, the Comisión Empresaria de Medios de Comunicación, Grupo Clarín, Grupo Vila- Manzano, and international organizations such as the Sociedad Interamericana de Prensa and the Asociación Internacional de Radiodifusión.

2. For more information on the litigation, see http://politicasyplanificacion.sociales.uba.ar/ files/2014/07/marino.pdf.

3. Created in 2010 and implemented by the Ministry of Federal Planning, Public Investment, and Services to improve daily communication for all of the country's inhabitants.

4. Created in April 2010 to revive and upgrade public schools and reduce digital, educational, and social gaps and implemented by the National Social Security Administration, the Ministry of Education, and the Ministry of Federal Planning, Public Investment, and Services. It distributed netbooks to all students and teachers in secondary schools, special education, and teacher training institutes under state management.

5. http://www.lamac.org (accessed March 4, 2014).

6. http://www.lamac.org (accessed March 4, 2014). 


\section{References}

AFSCA (Autoridad Federal de Servicios de Comunicación Audiovisual)

2012 Informe anual sobre contenidos de la televisión abierta argentina (Origen de la producción, tipo de programación, estructura de propiedad), año 2011. Buenos Aires: AFSCA.

Albornoz, Luis and Trinidad García Leiva

2012 “Televisión digital terrestre: caracterización, antecedentes e importancia,” pp. 23-42 in L. Albornoz and T. García Leiva (eds.), Televisión digital terrestre. Buenos Aires: La Crujía.

Becerra, Martín

2014 “Convergencia y políticas culturales: una agenda pendiente.” http://recursosculturales .com/revista/2014/06/convergencia-y-politicas-culturales-una-agenda-pendiente/ (accessed June 20, 2014).

Becerra, Martín and Guillermo Mastrini

2009 Los dueños de la palabra. Buenos Aires: Prometeo.

Bustamante, Enrique (ed.).

2003 Hacia un nuevo sistema mundial de comunicación: Las industrias culturales en la era digital. Barcelona: Gedisa.

Galperín, Hernán

2004 New Television, Old Politics: The Transition to Digital TV in the United States and Britain. New York: Cambridge University Press.

Marino, Santiago

2013 Vaivén:Desgranarmoralejas en la Argentina dela leyaudiovisual. Observatorio Latinoamericano del Instituto de Estudios de América Latina y el Caribe Dossier no.14. Buenos Aires: Facultad de Ciencias Sociales, UBA.

Marino, Santiago, Guillermo Mastrini, and Martín Becerra

2010 “El proceso de regulación democrático de la comunicación en Argentina." Oficios Terrestres

$16(25): 11-24$.

Mosco, Vincent

2006 "La economía política de la comunicación: una actualización diez años después."

Cuadernos de Información y Comunicación 11: 57-79.

Pasquali, Antonio

1991 El orden reina: Escritos sobre comunicaciones. Caracas: Monte Avila.

Rodríguez Miranda, Carla

2010 "La adopción de ISDB-T para la televisión digital terrestre en la Argentina." Revista Ecos de la Comunicación 3 (3): 77-106.

Van Dijk, Jan and Kenneth Hacker

2003 "The digital divide as a complex and dynamic phenomenon." Information Society, no. 19, 315326.

Zallo, Ramón

1988 Economía de la comunicación y la cultura. Madrid: Akal. 
Carla Rodríguez Miranda teaches social sciences at the Universidad Nacional de Quilmes and the Pontificia Universidad Católica Argentina. She is a Ph.D. candidate at the Universidad de Buenos Aires and has a Master's in cultural industries. Ornela Carboni teaches and holds a research fellowship from the Consejo Nacional de Investigaciones Científicas y Técnicas at the Universidad Nacional de Quilmes and has a Ph.D. in social sciences from the Universidad de Buenos Aires. She manages the project "Los procesos de organización productiva y del trabajo en el escenario convergente y digital de la industria audiovisual argentina" and is coeditor, with Guillermo Mastrini, of Siete debates nacionales en políticas de comunicación: Actores, convergencia y tecnología (2012). Victoria J.

Translated by Victoria J. Furio

Furio is a translator living in New York City. 